\section{DE DE GRUYTER} OPEN
Journal of Intercultural Management

Vol. 6, No. 4, part II, December 2014, pp. 5-14

DOI 10.2478/joim-2014-0052

\author{
Agnieszka Wróblewska-Kazakin ${ }^{1}$ \\ Politechnika Częstochowska
}

\title{
Determinants of Family Business Progress
}

\begin{abstract}
The aim of this article is to indicate the characteristics, which make family business prominent in the free market. Perceiving these characteristics as values of family business gives them the opportunity to gain competitive advantage and enables multi-generation existence of the company. The process of succession, if conducted in a planned and formalized way, becomes a value itself. The two projects: 'The guide to succession' and 'Value codes', both in the testing phase, promoting the process of succession in Polish family firms, have set the creating of complex tools enabling the succession in the family business to be effected their target.
\end{abstract}

Keywords: family business management, building values, organization, culture, communication, process of succession

\section{Introduction}

The aim of this article is to indicate the characteristics, which make family business prominent in the free market. Perceiving these characteristics as values of family business gives them the opportunity to gain competitive advantage and enables multi-generation existence of the company. Family business is the symbiosis of two worlds: family and business. What help distinguish the family business from the non-family business are the realms of value and the organization culture. In turn, the organization culture, based on family bonds and values, is the factor determining competitive advantage on the market.

According to prof. Peter May: 'family entrepreneur builds his company upon values, which are of importance to him. It is an invisible thread, strong and tenacious, affiliating generations of family business.'

The reference books often display family firms as a system [Cohn 1992, p. 34] of three intersecting subsystems: family, company and property. It has been illustrated below. 


\section{Illustration 1. Family business as a system}

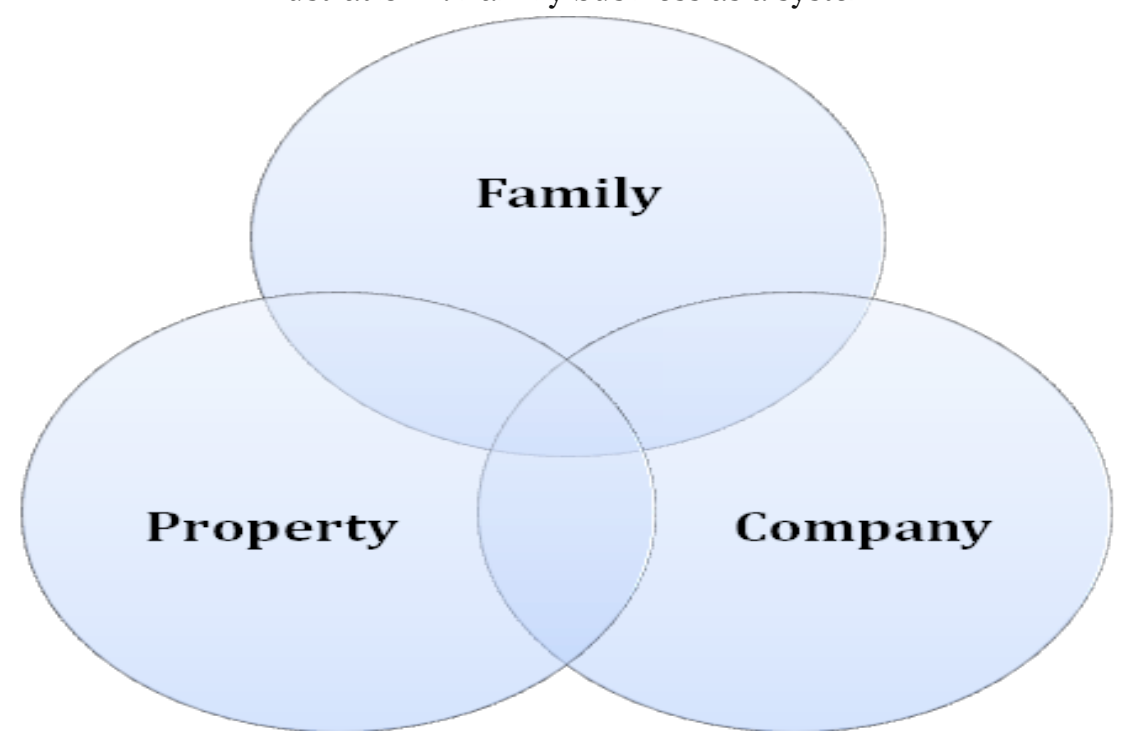

Source: M. Cohn, Passing the Torch, Succession, Retirement \& Estate Planning in Family - Owned Businesses, McGraw-Hill Inc., New York 1992, p. 34.

The intersection of Family and Company are the family members employed in the company with no proprietary right to the company, those family members not working for the company but with the proprietary right to a part of the enterprise constitute the intersection of Family and Property. In turn, the intersection of Property and Company are people not being members of the family but working for the company and having proprietary rights to a part of it. The intersection of all the subsystems is the owner of the enterprise and the heritors who work in the company and therefore, have proprietary rights to a part of it.

Various definitions of family business may be found in numerous sources concerning family entrepreneurship. As a result, it is problematic to define a business as a family business or not. There is no normative description of family business as such, and the obligation to file the reports to be used in statistic data does not distinguish 'family business' as a separate category. Treating the sector of small and medium sized enterprises as family business is not appropriate and does not underline the character of its functioning since a number of family firms belong to the category of large enterprises., such as: ITI, Fakro, Konspol, Witchen, Solaris or Dr. Irena Eris.

The Oregon State university has provided an original, however, not precise definition of family business [Winnicka-Popczyk 2002, p. 201], and that is: if a family claims that its firm is a family firm, it is one, indeed. Brzeziński still proposes 
other definition according to, family business it so, which amongst stakeholders the family of the owner is in [2012, Employees, p. 279].

\section{Factors determining success of family business}

Family business, in large measure, owe their economic success to an informally assumed system of values [Popczyk A. and W. 1996, p. 85], which passed down from generation to generation has become a code of conduct to future owners, employees and the organization as such. The strengths of family firms described in the reference books are as follows [Korda 2010, p. 6]:

- Flexibility,

- Appropriate public relations,

- Innovation planning,

- Positive atmosphere at workplace,

- Long term prospects,

- Investment plans.

The weaknesses pointed out by Korda [2010, p. 6] are often connected with such factors as:

- Familism,

- Underappreciating employees from 'outside of the family',

- Unwillingness to employ professional managers from 'the outside',

- Keeping away from the know - how from 'the outside',

- Lack of clear development strategy,

- Lack of legal and tax planning culture,

- Underappreciating the issue of succession,

- No succession plan,

- Lack of appropriate preparation for the successor.

Taking the above strengths of family firms into consideration - flexibility being the first mentioned virtue, appears in the adapting aptitude and fast reaction to changes. That favours innovation and creativity, which result in the increase of technological level and the quality of services offered. Intuition and personal, longstanding experience, which builds such virtues as: honesty and tradition are also important. Good public relations and positive atmosphere, in turn, build up trust, loyalty and result in the sense of social responsibility. Innovation planning means avoiding risky ventures, concentrating on moderate development and building an enterprise sensibly aiming at stability in the company and its duration for next generations.

Considering the above issues of family business functioning, Korda [2010, p.6] mentions familism to be an obstacle in the development of the company. The former factor, defined as negative, should be treated as transferring business problems onto the family ground and vice versa. It does not mean that business matters should not be discussed during family dinners. However, those discussions should gain a form 
of discourse, opinion exchange leading to improvement. The second factor, defined as negative, that is the feeling of underappreciation of employees 'from outside of the family', is not justified. From the point of view of employees, it might appear as if they were underappreciated since their chances of promotion compared to those of family members are rather low. However, the organization culture of family firms should allow understanding of both, employers and employees. An employee is endeavouring to assume his/her responsibilities and challenges family members; in most cases the commitment and knowledge are rewarded. Understandably, relying on members of family is caused on the strong bonds, whereas an employee from the outside may want to leave at any time. It depends on each of us what is of greater importance: material aspects or stability of employment, friendly relationships with co-workers, loyalty and honesty, which characterize organization culture of family business. Another reason yet, is that the family members employed in the business also feel the discomfort when colleagues only perceive them as a boss's 'child' and not a competent employee on the appropriate position. The next factors: unwillingness to employ professional managers from 'the outside', keeping away from the know - how from 'the outside', lack of clear development strategy and legal culture stem from the fact that the owners - founders of the family business are convinced that if their business based on intuition and experience has lasted, it will last. It is also connected with the lack of knowledge on the necessity of planning the succession process.

\section{Communication as a key factor of family business success}

Communication is a crucial element of family business functioning connecting the owner with the successor, the owner and the employees and the successor with the employees. It is a factor of success when the nestor and the successor have a partner not parental relationship, and the employees are informed about the forthcoming changes, which eliminates anxiety concerning the fate of the company. If the nestor believes that the successor will handle the duties, the anxiety of the subordinates will be quashed. The paternal management style so predominant in family business creates a strong bond between the management and employee, the feeling of belonging to the family and 'the boss' is the one who will always find a solution to every problem.

Communication is also valid when it comes to relationships between employees and successors. The successor, instead of implementing changes often difficult to accept while what is already in practice brings intended effects, should rely on the knowledge of experienced employees working for the company for many years or even from its early beginnings. If that does not happen, the successor becomes untrustworthy in the eyes of coworkers, and is neither supported nor even accepted.

It is, therefore, important that nestors give their children an opportunity, not being afraid to pass down the power, but first of all not being afraid to believe in 
the further success, which is the aspect mentioned not only by the owners but also by successors as a 'rather important' aspect in terms of concerns against succession. 'Trust in the future success of the company' is thus a factor most highly rated according to the research carried out under the project 'Value codes - effective succession in Polish family business' [Value Codes, p.15]².

Communication also means joint decision-making regarding the vision of the enterprise functioning and creating its mission. Dr. Herwig Friedag show that nestors do not agree with their successor the vision of future management what, in long term, may lead to complete change in the concept of running the business. Therefore, it is vital to define the market strategy (external potential) and the family constitution (internal potential) together, so that the disputable issues are known from the beginning and may be discussed [Value Codes, p. 20].

Prof. T. Budziak [2012] has also discussed the family constitution as an indispensable element of family business success. It constitutes a set of certain rules, which allow long-term enterprise development plans to be created and to come into effect. The family constitution helps identify the areas of conflict - those existing and the potential ones. He clearly states the roles of family members to ensure the cohesion of family and company. The constitution of family should include the following elements [Widz, www.sukcesja.org.pl]:

- Vision and mission of the family - defining the value of the family, the value of the family business and the owners' vision;

- General statements - who belongs to the family, what are the rules concerning decision-making in the family and the rules concerning changes in the constitution;

- Regulations concerning the family in the business - employing family members and their payment, defining their share in the business and the family bodies (e.g. family gathering);

- Family policy concerning the business - appointing family bodies (e.g. board of directors or advisory board), board of directors, succession plan, code of conduct in relationships between family members and stakeholders;

- Financial policy of the company.

The Polish family business research has demonstrated that the above issues are nonexistent and most founders expect the comparable style of managing the business by their descendants.

2 Any other factor was not considered as 'very important'. 'Value codes -the diagnosis of the current state of ownership in Polish family firms' - a summary report based on research conducted in the project 'Value codes -effective succession in Polish family firms' - including the summary of the results of research conducted between 1 November 2012 - 9 February 2013 as part of the task Diagnosis, i.e. in the first stage of the project. The project is implemented by the Higher Education Development Centre TEB Akademia ltd, Business Discovery Adrianna Lewandowska and Hortimex Plus ltd. limited partnership and is also co-financed by the European union from the European Social Fund [www.sukcesja.org.pl]. 


\section{Succession as a determinant of family business success}

The process of succession should be planned and formalized. Dr. A. Marjański rightfully argues that 'having a good intergenerational plan enables, in most cases, retaining sufficient condition of a business and appropriate family relationships. Succession planning clarifies the organization pattern and helps implement order in the role of the family and avoid conflicts concerning proprietary rights and management' [Marjański, Value Codes, p. 6].

One of the determinants of success is for the nestors to understand the necessity of his/her retirement. Most Polish family firms are enterprises of first generation founders who identify themselves fiercely with the company treating it as their child. Peter May has defined it appropriately: 'after retreating from business responsibility, founders need new challenges. When somebody has run a business for many years, they don't want to become a couch potato, read books, travel or play golf at the age of 65. An entrepreneur potential needs to be allocated somewhere, for instance, in leading a football team, taking over a hotel or founding a college' [May, Value Codes, p. 22].

The second success factor in the process of succession is the necessity to confront parent's authority by the successor. In that case, the relationship between the parent and the successor is significant. It should be based on business partnership more than on the arrangement fathers/mother - son/daughter.

The Austrian Spängler family owners of the private bank Bankhaus Spängler, have defined main objectives of the bank in their business mission including the will to retain independent, at the same time admitting that being independent equals moderate development. Such conduct characterizes majority of Polish family firms with long experience on the market. Other key entry in the mission of the above enterprise is that remaining the family business is feasible, if the company is controlled by the family but not necessarily governed by them. Polish entrepreneurs are sceptical towards the idea of delegating management duties to external managers [Brzeziński 2012, Owners, p. 156]. According to Heinrich Spängler, 'the most educated individuals from every generation should represent bank owners in the board', however, 'if the family do not get on well, or there is not such a person who might take the post, they should concentrate on their role as company owners leaving that post to a person from outside. Being a company managed by the family is not our priority.' Bankhaus Spängler has existed for 180 years ['Family business' 6/13, p. 22].

The first tools supporting activity of family firms in Poland, when it comes to strategic management, legal or financial aspects, are just being created. They become even more meaningful due to the current period in Polish economy, the first generation change, when owners -founders of family firms pass down the knowledge and experience in running a business to their already mature children. 
The awareness of Polish people regarding the entire process of succession has been increasing recently. It can be proved by the number of over 300 members of the Association of Family Business Initiative established in 2008, or by the number of family entrepreneurs using the 'Family business' sign which on 7 November 2013 has amounted to158 ['Family business' 6/13, p. 21]. Furthermore, the results of the report 'Value codes - the diagnosis of the succession process reality in family businesses in Poland' has revealed that as much as $74 \%$ of owners and $76,8 \%$ of successors realizes that succession is an important process in the company which needs to be planned in advance and managed in a professional way. Unfortunately, most of them do not comply with the rule. Almost 505 of the companies ( $47 \%$ of owners and $46 \%$ of successors) claim that bowing out will occur in the spoken form. Over $70 \%$ of owners and $75 \%$ of successor believe that the process of succession will take up to a year or even does not have to come into effect [Value codes, p. 7], while the research of succession on the Swiss market shows that the time ranges from 5 to 10 years. ${ }^{3}$

Let us hope that younger generation of Polish family business founders will be more aware of the complexity of the process of succession and as a result the future successors will be prepared for takeover much earlier. Certainly the tools improving the process of succession, such as 'The succession guide' or the already mentioned project 'Value codes', which are currently being created or in the testing phase, will prove helpful for the successors. The aim of the projects is to create complex tools improving independent succession in the family business. The process includes a few elements such as:

- Regulatory environment,

- Tax regulations,

- Development strategy,

- Property, division of assets,

- Securing nestors,

- Choosing successor.

Innovative tools conforming to specific needs of family business and future generations will be generated thanks to the testing process among the representatives of family businesses who are planning succession. 'Family business succession guide' is a project co-financed by the European Social Fund and implemented by the Economic Advisory Council to the Prime Minister. The aim of the project is a study and verification of the efficiency of the innovative tool designed to independently plan succession in family business [www.sukcesja.org/].

The tool, which will be the result of the project, includes the following elements: - Knowledge compendium on succession - a book, multimedia and audio book

3 The lecture entitled 'Succession in Family Firms' by Prof. Dr. Thomas Zellweger for the Center for Family Business at the University of St. Gallen, as part of the seminar 'Family Business' in the autumn semester of 2012. 
version with educational materials, animations, interactive exercises, films, etc.

- Two computer applications including:

- The analysis and diagnosis of the current state of ownership succession in the company (NOE analytical -diagnostic application) - having completed objective company data (financial, legal, organizational, personal) and subjective owners' opinions, the entrepreneur will automatically receive the analysis and diagnosis of the current state of the ownership succession on the strategic, organizational, personal, financial and legal level to be able to determine succession readiness;

- Planning succession (NEO planning application) - having considered the results of an earlier analysis and after answering questions about the most significant areas of succession, activity time range, potential and preparation of the successors, an initial succession activity plan with sequence of tasks and estimated time will be generated. Users may also adjust it to their individual circumstances.

Stages of participation in the project:

1. Consultations concerning the innovatory tool which took place between December 2012 and February 2013 helped gather family business owners' opinions on challenges in planning succession. They had to complete electronic survey or give an interview to the moderator in the company;

2. Testing the innovative tool in the form of 'Family business succession guide' during this stage, which is currently taking place, the Participant of the project are supposed to become familiar with the elements of the 'Guide' and comment to the producer on the utility and effectiveness of the tool in the planned succession. The entrepreneur testing the "Guide" may familiarise with it individually, in any place with access to computer. Comments concerning the tested tool should be reported in the form of a survey or an interview;

3. Improving the tool on the basis of feedback from the testers.

The assumed target is to maintain continuity of business functioning.

The project envisages 20 seminars for 300 family business owners, 2 all-Poland conferences for 300 owners and 100 stakeholders, 8 workshops on practical use of the Guide for 96 owners and guest participation in 5 conferences on family business support for the sector of small and medium enterprises.

The second project concerning succession in family business, which is in the phase of testing, is the project 'Value codes -effective succession in Polish family business'. The project is implemented by the Higher Education Development Centre TEB Akademia ltd, Business Discovery Adrianna Lewandowska and Hortimex Plus ltd. limited partnership and is also co-financed by the European union from the European Social Fund [www.sukcesja.org.pl].

The tool created in the project consists of the following elements: 
- Knowledge compendium on succession leading through the process of succession,

- SOS manual - in case of sudden succession,

- Inspiring and guiding animated series including the story of 'Delikatesy Dobre' company being in the course of succession and run by the Sierpińscy family.

- Audio book - with the story of the Sierpińscy family which is undergoing the process of succession,

- 58 tools guiding through the particular stages of succession,

- Knowledge portal including i.e. case study, tools, articles, research, forum, job market for the successors.

Particular stages of the Project are:

- Diagnosis - research conducted between 1 November 2012 and 9 February 2013.

While diagnosing the Project 'Value codes', 8 key determiners of family business success were defined [Value Codes, p. 21]. Its objective was, like in the already mentioned Project, maintaining continuity of the company by future generations. Those factors concentrate on the improvement of succession process and include:

1. Realizing 'what is about to happen' and the earlier we understand it, the more probable the success;

2. The analysis of the initial situation of the company;

3. Starting conversations about the succession;

4. Honest conversation with the family and future successors about the concerns and reaching an agreement;

5. The necessity of expanding the boundaries of responsibility for the company before giving power to the successor;

6. Realizing that the successor is learning and may commit mistakes which does not prove his/her incompetence or lack of preparation;

7. Finding an expert not only on legal matters but also on better communication and understanding of the process of succession when it the problem arises;

8. Planning personal activity after giving power before it happens.

Testing - downloading the tools and completing the testing survey is possible directly from the website www.sukcesja.org.pl.

The succession process involves many people and each group of recipients should have the tool adapted to their specific needs, therefore, in the above project we can distinguish testing tools for the owner-nestor, the board, the family, the successor, the employees and the contractors.

What makes the two projects outstanding is the possibility to perform the succession independently, without additional counseling costs or legal advice. Even in that range the values which determine family business are clearly visible, these are: mutual support, commitment, readiness for skill-sharing and creating something 
that can be used by future owners of family business facing the challenge 'what next'?

\section{Summary}

The tools, being now created, enabling independent, effective succession in Polish family businesses, provide an opportunity for endurance or even long - term development of family entrepreneurship. They constitute the grounds for common discussion and commitment of family members to build intergenerational bonds. A correct succession constitutes the greatest family business success.

\section{Bibliography}

Brzeziński A., (2012), Owners as SMEs' stakeholders, Zeszyty Naukowe Wyższej Szkoły Bankowej we Wrocławiu nr 32/2012, Poznań.

Brzeziński A., (2012), Employee as family businesses stakeholders, Zeszyty Naukowe Wyższej Szkoły Bankowej we Wrocławiu nr 28/2012, Poznań.

Budziak T., (2012), Succession in business family, Poltext, Warsaw.

Cohn M., (1992), Passing the Torch, Succession, Retirement, \& Estate Planning in Family - Owned Businesses, McGraw-Hill Inc., New York.

Value codes - the diagnosis of the current state of ownership in Polish family firms - a summary report based on research conducted in the project 'Value codes - effective succession in Polish family firms' - time of research 1.11.2012-9.02.2013.

Popczyk A. Popczyk W., (1996), Tradition and trouble, „Businessman” no 11.

Widz M., (2013), Family constitution - needless waste of time or necessity, www.sukcesja.org.pl [12 February 2014]

Winnicka-Popczyk W., (2002), Specific aspects of family business management, [in:] J. Hołubiec (red.) Contemporary management problems, Edition. MWSHP, Lowicz.

www.sukcesja.org/

www.sukcesja.org.pl 